\title{
Soft Tissue Sarcoma of the Retroperitoneum pT4 TNM Finding v8
}

National Cancer Institute

\section{Source}

National Cancer Institute. Soft Tissue Sarcoma of the Retroperitoneum pT4 TNM

Finding v8. NCI Thesaurus. Code C136806.

Soft tissue sarcoma of the retroperitoneum measuring more than $15 \mathrm{~cm}$ in greatest

dimension. (from AJCC 8th Ed.) 